\title{
The Immortal Life of Henrietta Lacks
}

The Immortal Life of Henrietta Lacks by Rebecca Skloot. Crown Publishers, 2010. ISBN:978-1-40005217-2 Hardcover-369 pages.

Henrietta Lacks (August 18, 1920, to October 4, 1951) was a poor Southern African-American tobacco farmer whose cancerous cervical tumor was the source of cells George Otto Gey at Johns Hopkins in Baltimore, Maryland, cultured. These "immortal" cells remain "alive," 60 years after her death, revolutionizing medical research.

In her 2010 book, The Immortal Life of Henrietta Lacks, Rebecca Skloot documents the histories of both the cell line-called the HeLa cell line after the first two letters of her first and last names to protect her identity-and the Lacks family. Henrietta's husband, David Lacks, was told little following her death. Suspicions fueled by racial issues prevalent in the South at the time were compounded by issues of class and education. Members of the Lacks family were kept in the dark about the existence of the tissue line, and when its existence was revealed in a 1976 Rolling Stone article by Michael Rogers, family members were confused about how Henrietta's cells could have been taken without consent and how they could still be alive 25 years after her death. Skloot's book takes the reader on an incredible journey from the "colored" ward of Johns Hopkins Hospital in the 1950s to the research laboratories with freezers full of HeLa cells, to Henrietta's small, dying town of Clover, Virginia, to east Baltimore, where Henrietta's children and grandchildren live.

The basic facts about the story of Henrietta Lacks are well documented. On February 1, 1951, Ms. Lacks visited Johns Hopkins because of a painful "knot" in her cervix and bloody vaginal discharge. After a biopsy, she was diagnosed with cervical cancer. The appearance of the tumor was unlike anything the examining gynecologist, Dr. Howard Jones, had seen. Prior to the treatment for the carcinoma, cells from the tumor were removed for research purposes without her knowledge or permission, which was standard procedure at that time. During her second visit eight days later, Dr. George Otto Gey obtained anoth- er sample of her tumor. These cells would eventually become the HeLa immortal cell line. In significant pain and without improvement, Lacks returned to Johns Hopkins Hospital on August 8 demanding admission and remained there until her death on October 4 at the age of 31. A subsequent partial autopsy showed that the cancer had metastasized throughout her body.

Gey "discovered that [Henrietta's] cells did something they had never seen before: They could be kept alive and grow." (p. 94) Cells obtained previously from other sources would survive for only a few days. Some cells in Lacks' tissue sample behaved differently than others. Gey was able to isolate one specific cell, multiply it and start the HeLa cell line. As the first human cells that could be grown in a lab and were "immortal" (did not die after a few cell divisions), they could then be used for many experiments. This represented an enormous boon to medical and biological research. It is estimated that total weight of all the HeLa cells ever grown exceeds 50 million metric tons.

The HeLa cells were vital for developing the polio vaccine and uncovering secrets of cancer, viruses and radiation effects. These cells led to improvements in in vitro fertilization, cloning, and gene mapping. Demand for the HeLa cells quickly grew. A special unit was established in Tuskegee Institute, Tuskeegee, Alabama, where African-American scientists helped grow the HeLa cells and also evaluated Dr. Jonas Salks's polio vaccine. "Black scientists and technicians, many of them women, used cells from a black woman to help save the lives of millions of Americans, most of them white. And they did so on the same campus-and at the very same time-that state officials were conducting the infamous Tuskegee syphilis study." (p. 97)

In 1932, 600 African-Americans, 399 with syphilis and 201 without, were enrolled in a study to investigate the natural course of syphilis. In 1947 penicillin was discovered as the drug of choice for syphilis, but the study patients were denied it. This federal government-sponsored study was projected to last six months, however, it continued for 40 years and was 
only stopped in 1972 after public outcry. After a \$10 million settlement, President Clinton in 1997 apologized on behalf of the nation.

Scientists worldwide have used Henrietta's cells for research in cancer, AIDS, the effects of radiation and toxic substances, gene mapping, and countless other scientific pursuits. HeLa cells have been used to test human sensitivity to tape, glue, cosmetics, and many other products. There are almost 11,000 patents involving HeLa cells.

Henrietta's family did not learn of her "immortality" until more than 25 years after her death, when scientists investigating HeLa began using specimens from her husband and children without informed consent. Her family also did not see any profits from the multimillion-dollar industry that sells human biological materials.

\section{Ethical Concerns}

Chester Southam, a well-respected cancer researcher and chief of virology at Sloan-Kettering Institute for Cancer Research, sought in February 1954 to see the effect of injecting HeLa cells in patients with cancer and in healthy controls. He decided to do this without informing the study subjects. When three junior doctors refused on the grounds that the study violated basic patients rights and the research was illegal, immoral, and deplorable, the issue was brought up in the press, and the New York State Board of Regents conducted hearings. The Board reprimanded Dr. Southam and suspended his license for a year. The National Institutes of Health also investigated and found that research on patients without informed consent was quite prevalent. This study identified the 22 most unethical studies from hundreds of unethical studies. Southam's study ranked number 17 in this infamous list. ${ }^{1}$ This spurred the need for the supervision of research and the necessity of having informed consent. (pp. 127-136)

\section{Unresolved Issues: Tissue Rights}

There are two key issues to deal with regarding tissue rights: consent and money. Up to now tissue research does not legally require informed consent. Storing blood and tissues is a routine procedure with no legal requirement for consent. It is estimated that in 1999 in the United States alone, there were more than 307 million tissue samples from more than 178 million people, and it is estimated that this number increases by 20 million samples each year. The unanswered question is determining the "ownership" of these biological products and cells. Once removed from a patient, does he have "ownership" of the tissue/cells and other biological materials?

However, it is clear to me that depriving the Lacks family of any financial gain from HeLa cells is not right. Deborah, Henrietta's daughter who provided most of the information for the book under review, pointedly asked: Had scientists cloned her mother? Had they killed her to harvest her cells? And if her mother was so important to medicine, why could her children not afford health insurance? The author describes Deborah as the soul of the book. Her spirit, her laughter, her pain, her determination and her unbelievable strength inspired the author to work more than 10 years to research and write the book.

In conclusion, I found the book very interesting, absorbing, and informative. Through this book the stories of modern medicine, the racial politics of medicine, bioethics, and race relations in United States are presented thoughtfully, and the Lacks family's painful story is presented with grace. The author, a young white Jewish female, had to struggle for a long time to win the family's confidence. Her 10-year effort has paid rich dividends, and to the author's credit she has established a scholarship fund for the descendants of Henrietta Lacks.

In May 2010, HBO announced that Oprah Winfrey and Alan Ball would develop a film project based on Skloot's book.

\section{Reference}

1. Beecher HK. Ethics and clinical research. N Eng J Med. 1966;274:1354-60. http://doi.org/g4t

\section{Book Review By}

Faroque A Khan, MB; MACP

Associate Editor, JIMA

Master American College of Physicians

Professor of Medicine

State University of New York

Stony Brook, New York 